\title{
Novel Mutation of the TGF- $\beta 3$ Protein (Loeys-Dietz Type 5) Associated With Aortic and Carotid Dissections
}

\section{Case Report}

Dargham Hussein, MD, Christian Olsson, MD, PhD, Kristina Lagerstedt-Robinson, MD, PhD, and Tiago Moreira, MD, PhD

Neurol Genet 2021;7:e625. doi:10.1212/NXG.0000000000000625
Correspondence

Dr. Moreira

tiago.more@gmail.com

\section{Abstract}

\section{Objectives}

Loeys-Dietz syndrome (LDS) is a rare genetic cause of stroke associated with connective tissue disorders but is not well known among stroke physicians. ${ }^{1}$ The main objectives of this case report are to increase awareness of this condition and to improve stroke prevention at follow-up visits.

\section{Methods}

A patient with aortic and carotid artery dissection who had undergone 2 major aortic surgeries with mechanical composite graft and treated with full-dose anticoagulation was reevaluated by neurologists due to retinal hypoperfusion symptoms. After musculoskeletal examination, cervical ultrasonography, and computerized tomography angiography, he was referred for wholegenome sequencing.

\section{Results}

We found joint hypermobility, skin hyperelasticity, bifid uvula, and combined cervical artery dissections that caused intermittently decreased blood flow in the left ophthalmic artery and an acute asymptomatic embolic stroke. A novel pathogenic variant of LDS type 5 consisting of a heterogeneous nonsense variant c.1044C >A, p. (Cys384*) was found in the TGF- $\beta 3$ (TGFB3) gene. Consequently, anticoagulation was intensified, and at 1-year follow-up, the patient's symptoms improved.

\section{Discussion}

This novel genetic variant coupled to the patient's phenotype contributes to the knowledge of genetic causes of stroke. Patients with multiple arterial dissections and musculoskeletal features should be offered genetic testing and be carefully evaluated to avoid further cerebrovascular ischemic lesions.

\footnotetext{
From the Department of Neurology (D.H.), Sankt Goran Hospital; Department of Molecular Medicine and Surgery (C.O., K.L.-R.), Karolinska Institutet; Department of Clinical Genetics (K.L.-R.), Department of Cardiovascular Medicine (C.O.), and Department of Neurology (T.M.), Karolinska University Hospital; and Department of Clinical Neuroscience (T.M.), Karolinska Institutet, Stockholm, Sweden. 


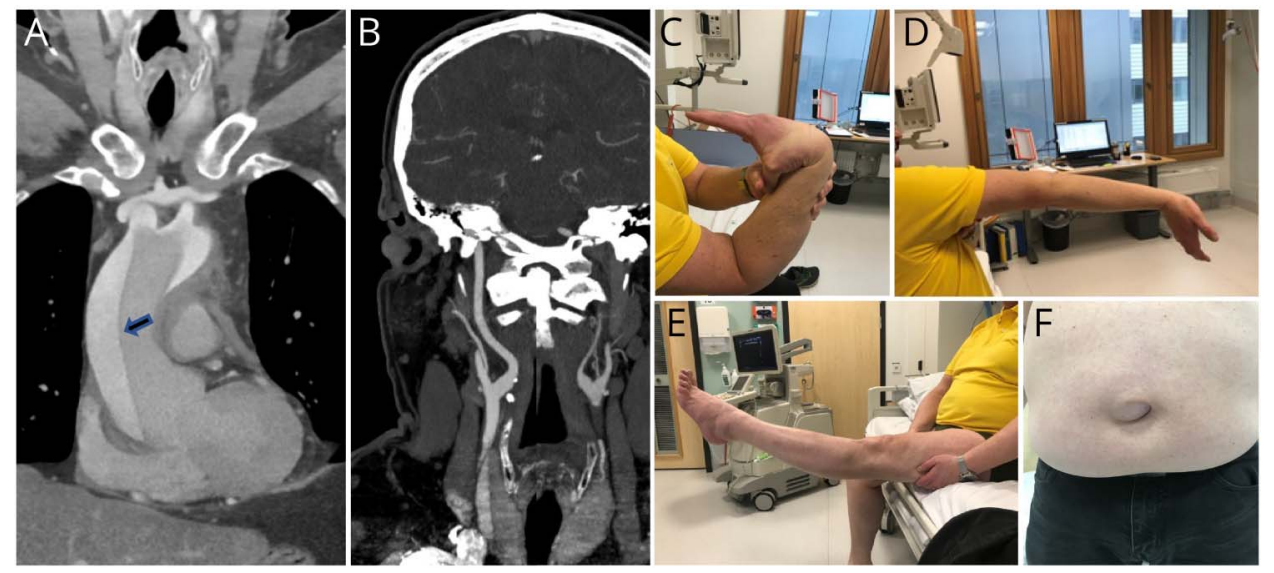

$\mathrm{CT}$ angiography (CTA) showing aortic dissection membrane (black arrow, A). Coronal reconstruction of CTA showing right common carotid artery (CCA) dissection and left CCA occlusive dissection extending to the internal carotid artery (B). Passive apposition of the thumb to the flexor aspect of the forearm (C). Passive hyperextension of the elbow beyond $10^{\circ}(\mathrm{D})$. Passive hyperextension of the knee beyond $10^{\circ}(\mathrm{E})$. Postoperative umbilical hernia (F).

\section{Case Report}

A 54-year-old man with a history of congenital hip luxation underwent acute surgery and supracoronary graft in the ascending aorta in 2018 due to a Stanford type A, Debakey type I aortic dissection. Follow-up CT angiography showed a rapid dilatation of the proximal descending aorta, from 37 to $57 \mathrm{~mm}$ (Figure, A).

He was reoperated in 2019 with replacement of the aortic arch using a frozen elephant trunk technique followed by individual reimplantation of the cervical vessels and replacement of the aortic root with a mechanical composite graft and thereafter prescribed oral warfarin.

Postoperative follow-up computerized tomography angiography showed proximal right common carotid artery (CCA) dissection and an occluded left CCA (Figure, B). During several months, the patient experienced dizziness and monocular visual loss induced by head rotation to the left.

Carotid duplex ultrasound at our department confirmed patency of the right CCA (peak systolic velocity/end diastolic velocity $=142 / 15 \mathrm{~cm} / \mathrm{s}$ ) and right internal carotid artery (ICA, $75 / 17 \mathrm{~cm} / \mathrm{s}$ ). The left CCA was occluded, and the left ICA had a steal morphology $(42 / 10 \mathrm{~cm} / \mathrm{s})$. Lower flow velocities in the left ophthalmic artery were detected with the patient's head turned to the left $(28 / 10 \mathrm{~cm} / \mathrm{s}$ vs $46 / 11 \mathrm{~cm} / \mathrm{s}$ in neutral head position), indicating retinal artery hypoperfusion. Flow velocities in the right ophthalmic artery remained unchanged during head rotation $(55 / 16 \mathrm{~cm} / \mathrm{s})$. Brain CT showed an asymptomatic small-sized acute ischemic infarct in the right superior frontal gyrus. Consequently, oral anticoagulation was adjusted to international normalized ratio (INR) target of 2.5-3.5 due to an initial INR of 2.1.

The patient informed us about previous joint dislocations. Physical examination showed skin hyperextensibility and joint hypermobility (Figure, C, D, and E), scoring 6 points on the Beighton scale score. Findings included pectus carinatum, bilateral pes cavus, bifid uvula, and unexpected postoperative umbilical hernia (Figure, F). In addition, one of his daughters had joint hypermobility. His mother had died suddenly at age 74 years of undetermined cardiovascular cause and had joint hypermobility. Whole-genome sequencing analyzing coding, splicing, and structural variants regarding 141 genes involved in connective tissue disorders ${ }^{2}$ identified a heterogeneous nonsense variant in the TGFB3 gene (NM_003239.4) c.1044C>A, p. $($ Cys384*), which is associated with LoeysDietz syndrome (LDS) type 5 .

\section{Discussion}

LDS was first described in 2005 but remains relatively unknown. Since 2005, 5 major subtypes have been identified in relation to the gene mutations found in the transforming growth factor (TGF)- $\beta$ receptor (types 1 and 2 ), TGFB 2 and 3 receptor ligands (types 4 and 5), or the small mothers against decapentaplegic homolog proteins 2 and 3, which are downstream transcription factors for cell growth, angiogenesis, apoptosis, and tumor inhibition (type 3 ). ${ }^{3}$ LDS type 5 , caused by TGFB3 mutations situated in chromosome $14 q 24.3$, is associated with aortic aneurysms and dissections involving the thoracic and/or abdominal aorta. Other features may include bifid uvula (links.lww.com/NXG/A475), cleft palate, mitral valve disease, skeletal overgrowth, cervical spine instability, and clubfoot deformity, although the phenotype varies largely between patients. ${ }^{3-5}$

The variant found in our patient, c.1044C >4, p. $($ Cys384*), located in a functional TGF domain, is novel and was found using whole-genome sequencing analyzing 141 genes causing connective tissue disorders. It has not been found, either in the normal population (gnomAD) ${ }^{6}$ or in patients. Other pathogenic sequence variants in the TGFB3 gene have been reported in 
children and adults and include missense substitutions (c.898C > G, p.(Arg300Gly), c.898C > T, p. (Arg300Trp) and c.899G >A, p.(Arg300Gln), c.1226G >A, p.(Cys409Tyr)), nonsense (p.Tyr365*), frameshift (c.704del, p.Asn235Metfs $^{*} 11$ and c.1102_1105del, p.(Leu368Thrfs* 18$)$ ), and splice site $(c .754+2 \mathrm{~T}>\mathrm{C})$ variants. The patient's family members could potentially be mutation carriers and will be offered genetic counseling. A correlation with known mutations of this gene and the clinical features of our patient suggests that this variant is pathologic.

This case report emphasizes the vascular vulnerability of an aberrant TGFB signaling pathway. The multiple dissections predisposed our patient to retinal hypoperfusion. Acute ischemic infarcts have been reported in adults with LDS emphasizing the importance of thorough neuroradiology, ultrasonography, and thoracic radiology to prevent serious neurologic complications. ${ }^{7}$ At 1-year follow-up, our patient reported visual symptoms to occur more seldom and did not experience any dizziness recurrence. Cervical ultrasound showed an improvement of the left ICA dissection, which no longer exhibited any steal phenomenon, and flow velocities in the ophthalmic arteries were symmetrical. The patient did not report any new stroke symptoms or hemorrhagic complications with the higher INR target.

In conclusion, this report illustrates the need for early phenotype recognition of LDS, which may overlap with EhlersDanlos and Marfan syndromes, highlighting a potential underrecognized genetic cause of ischemic stroke.

\section{Study Funding}

No targeted funding reported.

\section{Disclosure}

The authors report no disclosures relevant to the manuscript. Full disclosure form information provided by the authors is available with the full text of this article at Neurology.org/NG.

\section{Publication History}

Received by Neurology: Genetics April 15, 2021. Accepted in final form August 19, 2021.
Appendix Authors

\begin{tabular}{|c|c|c|}
\hline Name & Location & Contribution \\
\hline $\begin{array}{l}\text { Dargham } \\
\text { Hussein, MD }\end{array}$ & $\begin{array}{l}\text { Department of Neurology, } \\
\text { Sankt Goran Hospital, } \\
\text { Stockholm, Sweden }\end{array}$ & $\begin{array}{l}\text { Drafting/revision of the } \\
\text { manuscript for content, } \\
\text { including medical writing } \\
\text { for content; study concept } \\
\text { or design; and analysis or } \\
\text { interpretation of data }\end{array}$ \\
\hline $\begin{array}{l}\text { Christian } \\
\text { Olsson, MD, } \\
\text { PhD }\end{array}$ & $\begin{array}{l}\text { Department of Molecular } \\
\text { Medicine and Surgery, } \\
\text { Karolinska Institutet; } \\
\text { Department of } \\
\text { Cardiovascular Medicine, } \\
\text { Karolinska University } \\
\text { Hospital, Stockholm, } \\
\text { Sweden }\end{array}$ & $\begin{array}{l}\text { Drafting/revision of the } \\
\text { manuscript for content, } \\
\text { including medical writing } \\
\text { for content, and major role } \\
\text { in the acquisition of data }\end{array}$ \\
\hline $\begin{array}{l}\text { Kristina } \\
\text { Lagerstedt- } \\
\text { Robinson, MD, } \\
\text { PhD }\end{array}$ & $\begin{array}{l}\text { Department of Molecular } \\
\text { Medicine and Surgery, } \\
\text { Karolinska Institutet, } \\
\text { Stockholm, Sweden; } \\
\text { Department of Clinical } \\
\text { Genetics, Karolinska } \\
\text { University Hospital, } \\
\text { Stockholm, Sweden }\end{array}$ & $\begin{array}{l}\text { Drafting/revision of the } \\
\text { manuscript for content, } \\
\text { including medical writing } \\
\text { for content; major role in } \\
\text { the acquisition of data; and } \\
\text { analysis or interpretation of } \\
\text { data }\end{array}$ \\
\hline $\begin{array}{l}\text { Tiago Moreira, } \\
\text { MD, PhD }\end{array}$ & $\begin{array}{l}\text { Department of Neurology, } \\
\text { Karolinska University } \\
\text { Hospital, Stockholm, } \\
\text { Sweden; Department of } \\
\text { Clinical Neuroscience, } \\
\text { Karolinska Institutet, } \\
\text { Stockholm, Sweden }\end{array}$ & $\begin{array}{l}\text { Drafting/revision of the } \\
\text { manuscript for content, } \\
\text { including medical writing } \\
\text { for content; major role in } \\
\text { the acquisition of data; } \\
\text { study concept or design; and } \\
\text { analysis or interpretation of } \\
\text { data }\end{array}$ \\
\hline
\end{tabular}

\section{References}

1. Loeys BL, Chen J, Neptune ER, et al. A syndrome of altered cardiovascular, craniofacial, neurocognitive and skeletal development caused by mutations in TGFBR1 or TGFBR2. Nat Genet. 2005;37(3):275-281.

2. Stranneheim H, Lagerstedt-Robinson K, Magnusson M, et al. Integration of whole genome sequencing into a healthcare setting: high diagnostic rates across multiple clinical entities in 3219 rare disease patients. Genome Med. 2021;13:40.

3. Weiss A, Attisano L. The TGFbeta superfamily signaling pathway. Wiley Interdiscip Rev Dev Biol. 2013;2(1):47-63.

4. Bertoli-Avella AM, Gillis E, Morisaki H, et al. Mutations in a TGF-beta ligand, TGFB3, cause syndromic aortic aneurysms and dissections. J Am Coll Cardiol. 2015; 65(13):1324-1336.

5. Loeys BL, Schwarze U, Holm T, et al. Aneurysm syndromes caused by mutations in the TGF-beta receptor. N Engl J Med. 2006;355(8):788-798.

6. Karczewski KJ, Francioli LC, Tiao G, et al. The mutational constraint spectrum quantified from variation in 141,456 humans. Nature. 2020;581(7809):434-443.

7. Laterza D, Ritelli M, Zini A, et al. Novel pathogenic TGFBR1 and SMAD3 variants identified after cerebrovascular events in adult patients with Loeys-Dietz syndrome. Eur J Med Genet. 2019;62(10):103727. 


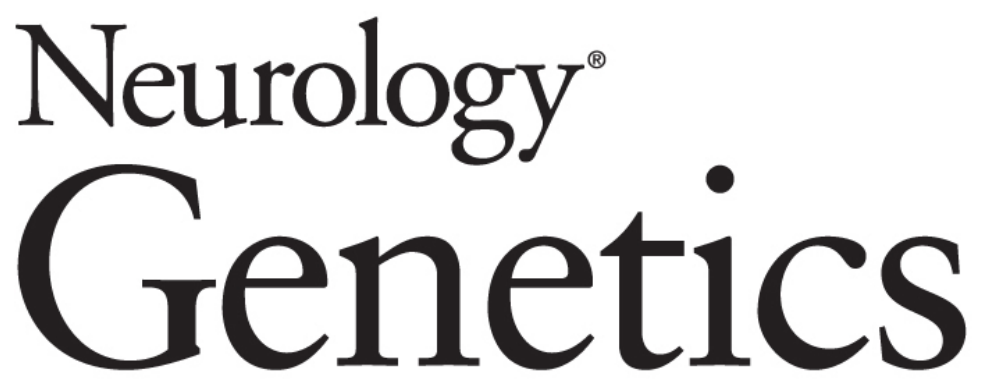

Novel Mutation of the TGF- $\beta 3$ Protein (Loeys-Dietz Type 5) Associated With Aortic and Carotid Dissections: Case Report

Dargham Hussein, Christian Olsson, Kristina Lagerstedt-Robinson, et al. Neurol Genet 2021;7;

DOI 10.1212/NXG.0000000000000625

This information is current as of September 15, 2021

Neurol Genet is an official journal of the American Academy of Neurology. Published since April 2015, it is an open-access, online-only, continuous publication journal. Copyright Copyright (C 2021 The Author(s). Published by Wolters Kluwer Health, Inc. on behalf of the American Academy of Neurology.. All rights reserved. Online ISSN: 2376-7839.

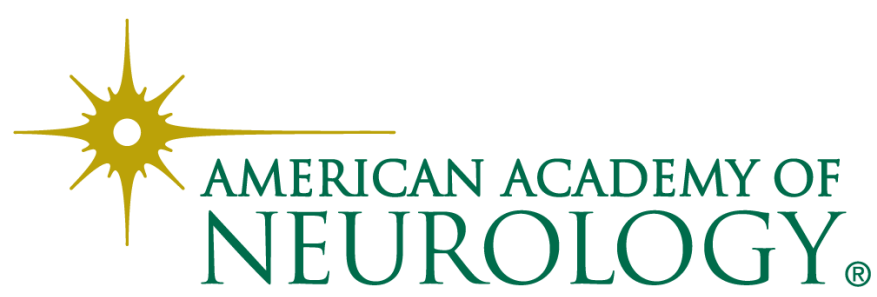




\section{Updated Information \& Services}

References

Subspecialty Collections

Permissions \& Licensing

Reprints including high resolution figures, can be found at:

http://ng.neurology.org/content/7/6/e625.full.html

This article cites 7 articles, 1 of which you can access for free at: http://ng.neurology.org/content/7/6/e625.full.html\#\#ref-list-1

This article, along with others on similar topics, appears in the following collection(s):

\section{All Cerebrovascular disease/Stroke}

http://ng.neurology.org//cgi/collection/all_cerebrovascular_disease_str oke

\section{Carotid artery dissection}

http://ng.neurology.org//cgi/collection/carotid_artery_dissection

\section{Class IV}

http://ng.neurology.org//cgi/collection/class_iv

\section{Embolism}

http://ng.neurology.org//cgi/collection/embolism

Stroke in young adults

http://ng.neurology.org//cgi/collection/stroke_in_young_adults

Information about reproducing this article in parts (figures,tables) or in its entirety can be found online at:

http://ng.neurology.org/misc/about.xhtml\#permissions

Information about ordering reprints can be found online:

http://ng.neurology.org/misc/addir.xhtml\#reprintsus

Neurol Genet is an official journal of the American Academy of Neurology. Published since April 2015, it is an open-access, online-only, continuous publication journal. Copyright Copyright $\odot 2021$ The Author(s). Published by Wolters Kluwer Health, Inc. on behalf of the American Academy of Neurology.. All rights reserved. Online ISSN: 2376-7839.

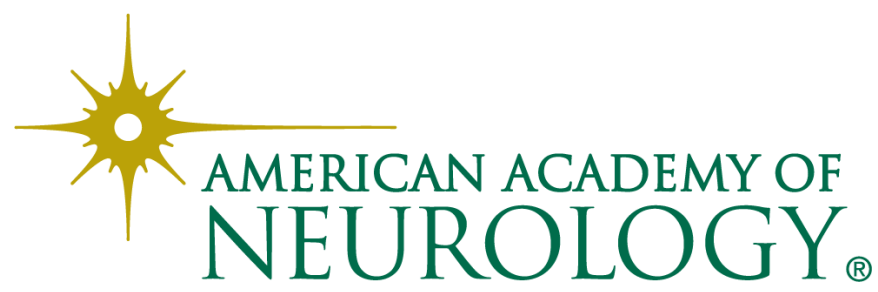

